\title{
Reologi, sifat aging, termal, dan swelling dari campuran EPDM/NR dengan bahan pengisi carbon black N220
}

\section{Rheology, aging, thermal and swelling properties of carbon black N220-filled EPDM/NR}

\author{
Arum Yuniari*, Dwi Wahini Nurhajati, Indiah Ratna Dewi, Ike Setyorini \\ Balai Besar Kulit, Karet, dan Plastik, Jl. Sokonandi No. 9, Yogyakarta 55166, Indonesia \\ *Penulis korespondensi. Telp.: +62 274 512929, 563939; Fax.: +62 274563655 \\ E-mail: arumyuniari@yahoo.com
}

Diterima: 22 Maret 2016 Direvisi: 18 Mei 2016 Disetujui: 20 Mei 2016

\begin{abstract}
The blends of EPDM and NR are immiscible in nature and incompatible. Introducing maleic anhydride as a compatibilizer into the blends was expected to produce compatible blends with balanced mechanical properties. The purpose of this research was to determine the effect of EPDM/NR ratio on the rheological, aging, thermal and swelling properties of the blends. The variation of EPDM/NR ratio were 100/0, 80/20, 70/30, 60/40, 50/50, and 40/60 phr. The blends were mixed using two roll mill. The results showed that the addition of NR affects the maximum torque, scorch time, and optimum vulcanization time. In the blends, EPDM plays an important role in improving aging, swelling, thermal properties.
\end{abstract}

Keywords: EPDM, natural rubber, rheology, aging, thermal, swelling.

\section{ABSTRAK}

EPDM dan NR merupakan polimer yang tidak misibel dan kompatibel. Penambahan kompatibiliser maleat anhidrat diharapkan menghasilkan campuran yang kompatibel dengan sifat mekanik yang baik. Pencampuran EPDM dan NR dilakukan menggunakan alat two roll mill, dengan rasio EPDM/NR adalah: 100/0, 80/20, 70/30, 60/40, 50/50, dan 40/60 phr. Tujuan dari penelitian ini adalah untuk mengetahui pengaruh rasio EPDM/NR terhadap sifat reologi, aging, termal dan swelling dari campuran EPDM/NR. Hasil penelitian menunjukkan penambahan NR mempengaruhi torsi maksimum, waktu scorch dan waktu vulkanisasi optimum. Penambahan EPDM memberikan sifat aging, termal dan swelling lebih baik.

Kata kunci: EPDM, karet alam, reologi, aging, termal, swelling.

\section{PENDAHULUAN}

Pencampuran dua polimer atau lebih secara kimia atau fisika merupakan upaya untuk membuat suatu material yang unggul. EPDM dan NR adalah polimer yang tidak misibel dan kompatibel, sehingga bila dicampur akan menghasilkan sifat mekanik kurang baik (Arayapranee \& Rempel, 2013). Penambahan kompatibiliser pada EPDM dapat memperbaiki reologi kompon dan meningkatkan kompatibilitas kompon (Lewis et al., 2003). Pencampuran EPDM/NR memberikan beberapa keunggulan antara lain peningkatan sifat fisik, ketahanan terhadap panas, oksigen, ozon, dan karakteristik proses, namun demikian campuran EPDM/NR memiliki kelemahan dalam hal perbedaan viskositas dan polaritas (Botros et al., 2009). Proses pembuatan kompon EPDM/NR menggunakan metode kuratif telah dilakukan oleh beberapa peneliti (Nabil et al., 2013a; Nabil et al., 2013b; Nabil et al., 2014; Indrajati \& Sholeh, 2014). Sifat mekanik, kinetika vulkanisasi, dan misibilitas dari campuran EPDM/NR telah dilaporkan (Sirqueira \& Soares, 2007a; Sirqueira \& Soares, 2007b; Razak et al., 2014). Penelitian tentang modifikasi campuran EPDM dan chloroprene dengan bahan pengisi marble sludge telah dilakukan (Ahmed et al., 2012). Nanokomposit NR/EPDM dengan bahan pengisi organoclay da- 
pat meningkatkan tegangan putus (Alipour et al., 2011). Karakteristik curing, kemampuan proses, sifat mekanik, aging, morfologi campuran NR/ EPDM dengan bahan pengisi silika, carbon black dan arang sekam padi telah diteliti (Arayapranee \& Rempel, 2008). Penggunaan titanium oksida pada campuran NR/EPDM dapat mereduksi waktu vulkanisasi campuran dan meningkatkan kristalinitas EPDM (Motaung et al., 2011). Dalam penelitian ini dipelajari pengaruh campuran EPDM/ NR dengan bahan pengisi carbon black N 220 dan kompatibiliser maleat anhidrat terhadap reologi campuran, sifat aging, termal, dan swelling.

\section{BAHAN DAN METODE Bahan Penelitian}

Bahan yang digunakan adalah: SIR 20 dari PTPN IX, karet sintetis jenis EPDM Keltan 4551 A, carbon black jenis N220 (Ex. Korea) sebagai filler, paraffin wax Antilux 654 A (Shandong Sianxian) sebagai anti oksidan, paraffinic oil (Indrasari, Semarang), seng oksida (Bratachem), asam stearat Aflux $42 \mathrm{M}$ (Rhein Chemie) sebagai aktivator, TMQ (Kemai), tetrametil tiuram disulfida (TMTD) dan merchapto benzothiazole (MBT) sebagai akselerator, serta sulfur sebagai bahan pemvulkanisasi ex. Miwon.

\section{Peralatan Penelitian}

Alat yang digunakan dalam penelitian ini meliputi alat proses dan alat uji terdiri atas: two roll mill, reometer merk Geotech $300 \mathrm{~A}$, hydraulic press MN Vulcanizing Press, Spec XLB, D 400 x
$400 \times 1$, timbangan digital merek Denver, tensile strength tester merek Kao Tieh model KT 7010A seri 70287 kapasitas 500 kg, DTA/TGA merek Perkin Elmer, DSC merek Perkin Elmer dan oven merek Memmert.

\section{Metode Penelitian}

Pembuatan kompon karet dilakukan dengan dalam dua bagian, yaitu kompon EPDM dan kompon NR (karet alam). Proses pencampuran kompon EPDM dilakukan dengan urutan sebagai berikut: EPDM, ZnO, asam stearat, N 220, paraffinic oil, TMQ, paraffin wax, TMT, MBT, dan sulfur. Kompon karet alam dibuat dari SIR 20, N220, MAH dan DCP digiling selama 25,58 menit. Kompon EPDM diuji kematangan komponnya menggunakan reometer pada suhu $160^{\circ} \mathrm{C}$ untuk memperoleh waktu scorch $\left(\mathrm{ts}_{2}\right)$ sebagai dasar menetukan waktu pemanasan awal (preheat). Waktu pema-

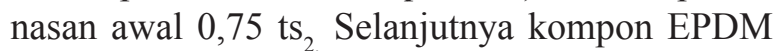
dicampur dengan NR selama 5 menit. Kompon campuran EPDM/NR disimpan dalam ruang kondisi selaama 24 jam sebelum divulkanisasi. Vulkanisasi dilakukan pada suhu $160^{\circ} \mathrm{C}$ dengan waktu sesuai reometer.

\section{Rancangan penelitian}

Dalam penelitian ini dilakukan variasi bahan baku yaitu perbandingan EPDM/NR seperti terlihat pada Tabel 1 .

\section{Pengujian}

Karakteristik reologi campuran diuji menggunakan reometer merek Gotech 300 A dilakukan pada suhu $160^{\circ} \mathrm{C}$, dimana yang diukur adalah torsi

Tabel 1. Formulasi campuran EPDM/NR dengan bahan pengisi carbon black N220.

\begin{tabular}{ccccccc}
\hline \multirow{2}{*}{ Bahan } & \multicolumn{7}{c}{ Formulasi } \\
\cline { 2 - 7 } & 1 & 2 & 3 & 4 & 5 & 6 \\
\hline EPDM & 100 & 80 & 70 & 60 & 50 & 40 \\
NR & 0 & 20 & 30 & 40 & 50 & 60 \\
C. Black N 220 & 80 & 80 & 80 & 80 & 80 & 80 \\
ZnO & 5 & 5 & 5 & 5 & 5 & 5 \\
Asam stearat & 1 & 1 & 1 & 1 & 1 & 1 \\
TMQ & 1 & 1 & 1 & 1 & 1 & 1 \\
Paraffin wax & 0,5 & 0,5 & 0,5 & 0,5 & 0,5 & 0,5 \\
Parafinic oil & 5 & 5 & 5 & 5 & 5 & 5 \\
TMTD & 1 & 1 & 1 & 1 & 1 & 1 \\
MBT & 1 & 1 & 1 & 1 & 1 & 1 \\
Sulfur & 0,8 & 0,8 & 0,8 & 0,8 & 0,8 & 0,8 \\
MAH & 3 & 3 & 3 & 3 & 3 & 3 \\
DCP & 0,9 & 0,9 & 0,9 & 0,9 & 0,9 & 0,9 \\
\hline
\end{tabular}


maksimum $\left(\mathrm{M}_{\mathrm{H}}\right)$ dan minimum $\left(\mathrm{M}_{\mathrm{t}}\right)$, delta torsi $\left(\Delta \mathrm{M}=M_{\mathrm{H}}-M_{\mathrm{L}}\right)$, waktu scorch $\left(\mathrm{ts}_{2}\right)$ dan waktu optimum vulkanisasi $\left(\mathrm{t}_{90}\right)$ sesuai ASTM: D 2084-11. Pengujian terhadap vulkanisat meliputi: tegangan putus dan perpanjangan putus awal dan sesudah aging pada suhu $100^{\circ} \mathrm{C}$ selama 70 jam (ISO 37). Pampat tetap sebelum dan sesudah perlakuan aging (ISO 815-2014). Pampat tetap awal dilakukan pada suhu kamar selama 22 jam, sedangkan pampat tetap sesudah aging dilakukan pada suhu $70^{\circ} \mathrm{C}$ selama 70 jam.

Pengujian termal menggunakan peralatan Thermogravimetric Analyser (TGA) dan Differential Thermal Analyser (DTA) merek Perkin Elmer. Sampel yang digunakan berat $10 \mathrm{mg}$ untuk TGA dan 23,169 mg untuk DTA, dipanaskan pada suhu $30-800^{\circ} \mathrm{C}$ dengan kecepatan $5^{\circ} \mathrm{C} /$ menit.

Pengamatan swelling dilakukan dengan cara perendaman sampel dalam n-heksana. Cuplikan ditimbang diudara kemudian direndam dalam nheksana selama 72 jam sesuai ASTM D 471. Cuplikan dikeringkan dengan kertas saring. Perubahan masa dihitung sesuai Persamaan (1).

Perubahan massa $\%=\left[\left(\mathrm{W}_{2}-\mathrm{W}_{1}\right) / \mathrm{W}_{1}\right] \times 100 \%$

$\mathrm{W}_{1}$ adalah massa sebelum dicelupkan dan $\mathrm{W}_{2}$ adalah massa sesudah dicelupkan.

\section{HASIL DAN PEMBAHASAN}

\section{Reologi Campuran}

Reologi campuran EPDM/NR dapat diketahui dengan peralatan reometer. Pengujian dengan reometer menyajikan data karakteristik pematangan masing-masing kompon yang meliputi: torsi maksimum $\left(\mathrm{M}_{\mathrm{H}}\right)$ dan minimum $\left(\mathrm{M}_{\mathrm{L}}\right)$, delta torsi $(\Delta \mathrm{M}=$ $\left.M_{\mathrm{H}}-M_{\mathrm{L}}\right)$, waktu scorch $\left(\mathrm{ts}_{2}\right)$ dan waktu optimum vulkanisasi $\left(\mathrm{t}_{90}\right)$.

Torsi maksimum $\left(\mathrm{M}_{\mathrm{H}}\right)$ kompon EPDM (Tabel 2) lebih tinggi dari pada kompon EPDM/NR, dengan demikian kompon EPDM mempunyai viskositas lebih tinggi. Peningkatan jumlah NR mengakibatkan $\mathrm{M}_{\mathrm{H}}$ akan turun. Maksimum torsi merefleksikan terjadinya jumlah ikatan silang. Penambahan NR mengakibatkan terjadi penurunan jumlah ikatan silang. Hal ini disebabkan NR bersifat non polar. Nilai torsi minimum $\left(\mathrm{M}_{\mathrm{L}}\right)$ dari semua kompon cenderung berfluktuasi. Perbedaan torsi maksimum dan minimum $\left(\Delta \mathrm{M}=M_{\mathrm{H}}-M_{\mathrm{L}}\right)$ mempresentasikan state of cure dan kerapatan ikatan silang. Selisih kedua nilai tersebut secara tidak langsung terkait dengan kerapatan ikatan silang total dari sebuah kompon (Nabil et al., 2013b). Kompon EPDM/NR mempunyai waktu scorch $\left(\mathrm{ts}_{2}\right)$ lebih tinggi dari kompon EPDM. Makin tinggi kandungan $\mathrm{NR}$, $\mathrm{ts}_{2}$ cenderung naik, hal ini menunjukkan dengan waktu scorch lebih lama kompon cenderung tidak mudah terdegradasi. Waktu optimum vulkanisasi $\left(\mathrm{t}_{90}\right)$ kompon EPDM/NR lebih tinggi dari pada kompon EPDM. Penambahan NR mengakibatkan waktu vulkanisasi kompon EPDM/NR cenderung lebih lama. $\Delta \mathrm{M}$ tertinggi terjadi pada kompon EPDM/NR (40/60) phr yaitu sebesar $(37,26) \mathrm{kg} . \mathrm{cm}$. Waktu scorch $\left(\mathrm{ts}_{2}\right)$ dan waktu curing $\left(\mathrm{t}_{90}\right)$ merupakan pengukuran waktu dimana vulkanisasi dimulai dan mencapai final. Kompon EPDM mempunyai waktu curing rendah $(5,01)$ detik. Makin tinggi kadar NR waktu curing naik, hal ini sesuai pendapat Arayapranee \& Rempel (2007). Namun pada jumlah karet alam $30 \mathrm{phr}$, waktu curing campuran EPDM/NR akan turun. Kompon EPDM/NR memiliki keamanan ts ${ }_{2}$ yang cenderung sama. Waktu curing vulkanisat EPDM/ NR (80/20 phr dan 70/30 phr) pembentukan ikatan silang lebih lama, sehingga waktu masak (curing time) waktunya $(13,47$ dan 10,14$)$ menit.

\section{Sifat Mekanik Sebelum dan Sesudah Aging}

Pencampuran antara EPDM dan NR dilakukan dengan metode kuratif, dimana sebelum EPDM dicampur dengan NR dilakukan preheating terlebih dahulu. Sifat mekanik yang tinggi dapat diperoleh bila accelerator yang tergabung dalam

Tabel 2. Karakteristik pematangan kompon.

\begin{tabular}{cccccc}
\hline EPDM/NR & $\begin{array}{c}\mathrm{M}_{\mathrm{H}} \\
\mathrm{kg} . \mathrm{cm}\end{array}$ & $\begin{array}{c}\mathrm{M}_{\mathrm{L}} \\
\mathrm{kg} . \mathrm{cm}\end{array}$ & $\begin{array}{c}\mathrm{ts}_{2} \\
\mathrm{detik}\end{array}$ & $\begin{array}{c}\mathrm{tc}_{90} \\
\text { detik }\end{array}$ & $\begin{array}{c}\Delta \mathrm{M} \\
\mathrm{kg} . \mathrm{cm}\end{array}$ \\
\hline $100 / 0$ & 65,12 & 8,39 & $0: 29$ & $5: 01$ & 56,73 \\
$80 / 20$ & 33,83 & 11,21 & $0: 51$ & $13: 47$ & 22,62 \\
$70 / 30$ & 44,79 & 14,76 & $0: 53$ & $10: 14$ & 30,03 \\
$60 / 40$ & 44,07 & 6,81 & $0: 43$ & $2: 31$ & 37,26 \\
$50 / 50$ & 39,11 & 3,84 & $0: 50$ & $2: 25$ & 35,27 \\
$40 / 60$ & 24,77 & 3,46 & $1: 11$ & $2: 59$ & 21,31 \\
\hline
\end{tabular}


kompon EPDM bermigrasi ke NR dan terdispersi secara merata dan menghasilkan distribusi ikatan silang yang homogen. Tegangan putus merupakan karakteristik penting dalam bahan polimer sebab menunjukkan batas beban maksimum yang dapat diterima oleh polimer tersebut. Tegangan putus EPDM/NR pada berbagai variasi untuk kondisi awal dan sesudah aging disajikan pada Gambar 1 .

Campuran EPDM dan NR merupakan campuran yang tidak kompatibel dan mempunyai interfacial adhesion lemah sehingga terjadi slip interlayer antara dua fase. Penambahan kompatibiliser maleat anhidrat diharapkan dapat menghasilkan campuran yang kompatibel. Jumlah NR semakin tinggi tegangan putus campuran EPDM/ NR cenderung semakin tinggi. Tegangan putus tinggi menunjukkan adanya distribusi ikatan silang homogen (Sahakaro et al., 2009). Jumlah NR tinggi waktu curing lebih lama (Tabel 1), sehingga terbentuk ikatan silang lebih banyak. Pengaruh termal aging terhadap sifat tegangan putus dari campuran EPDM/NR pada berbagai rasio (Gambar 1) menunjukkan adanya penurunan nilai tegangan putus disebabkan adanya deteorisasi dari campuran karena adanya pengaruh suhu. Perubahan tegangan putus karena NR dari matriks campuran lebih dahulu terdegradasi. NR lebih tidak tahan terhadap suhu bila dibandingkan EPDM. Penambahan EPDM terbukti memperbaiki sifat aging dari campuran. EPDM mempunyai struktur percabangan yang jenuh dan stabil dibandingkan NR (Patcharaphun et al., 2011; Arayapranee \& Rempel, 2007). Perpanjangan putus menunjukkan adanya keuletan, elastisitas atau fleksibilitas bahan karena pengaruh peregangan (stretching) sampai putus (Nabil et al., 2013a). Perpanjangan putus

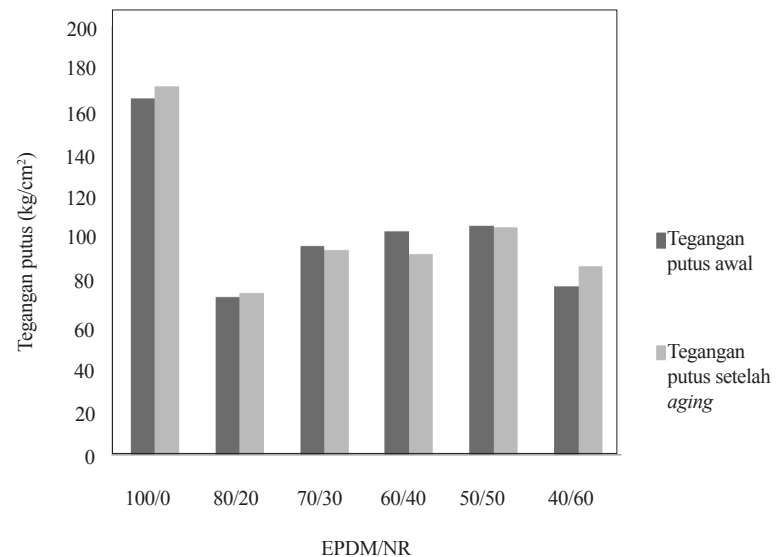

Gambar 1. Tegangan putus vulkanisat EPDM/NR sebelum dan sesudah aging. campuran EPDM/NR semakin tinggi jumlah NR perpanjangan putus cenderung tinggi. Disamping NR lebih elastis di banding EPDM, proses pencampuran dengan metode kuratif lebih banyak terbentuk ikatan silang. Campuran akan lebih elastis dan ulet. Perubahan perpanjangan putus campuran EPDM/NR setelah dilakukan aging disajikan pada Gambar 2. Sifat aging perpanjangan putus mempunyai kecenderungan sama dengan tegangan putus. Perpanjangan putus turun dengan bertambahnya jumlah EPDM (Arayapranee \& Rempel, 2007). NR memberikan sifat perpanjangan putus lebih tinggi di bandingkan EPDM, karena NR lebih kristalin. Penambahan EPDM ke dalam campuran sangat mempengaruhi siftat fisika setelah aging. Hasil penelitian menunjukkan perpanjangan putus relatif tidak mengalami perubahan atau perubahannya relatif kecil bila dibandingkan sebelum aging. Penambahan EPDM menyebabkan sifat kekakuan vulkanisat setelah aging berkurang sehingga nilai perpanjangan putus relatif tidak berubah. EPDM mempunyai sifat aging yang baik karena adanya diene yang tidak terkonjugasi (Sahakaro et al., 2009).

Vulkanisat EPDM mempunyai sifat pampat lebih baik dari pada campuran EPDM/NR (Gambar 3). Nilai pampat tetap vulkanisat campuran EPDM/NR cenderung kurang baik dengan semakin banyak jumlah NR. Nilai pampat tetap vulkanisat EPDM/NR pada kondisi suhu kamar selama 22 jam adalah (11,03-21,57)\%. Pampat tetap vulkanisat EPDM maupun EPDM/NR setelah perlakuan aging pada suhu $70^{\circ} \mathrm{C}$ selama 22 jam nilainya cenderung naik, hal ini disebabkan oleh rantai percabangan banyak yang putus akibat panas sehingga elastisitas turun.

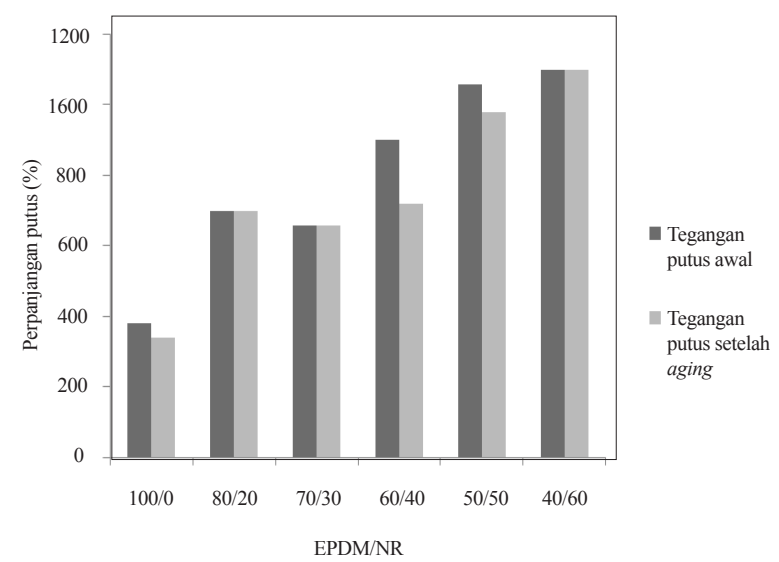

Gambar 2. Perpanjangan putus vulkanisat EPDM/ NR sebelum dan sesudah aging. 


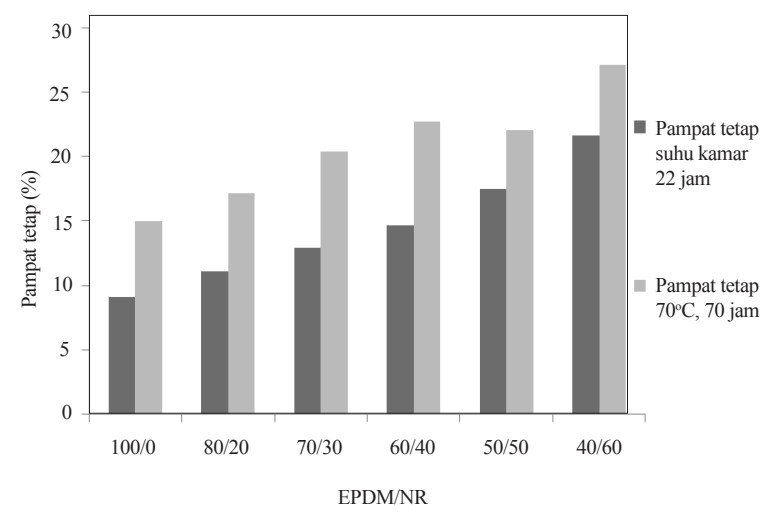

Gambar 3. Pampat tetap vulkanisat EPDM/NR sebelum dan sesudah aging.

\section{Karakteristik TGA dan DTA Vulkanisat EPDM/NR}

Analisis termogravimetri untuk mengetahui jumlah dan kecepatan perubahan massa bahan sebagai fungsi temperatur atau waktu dalam suasana yang terkendali. Pengukuran TGA terutama digunakan untuk suhu dan stabilitas oksidasi suatu bahan serta sifat komposisi bahan (Nabil et al., 2013a). Sifat dekomposisi dari derivat EPDM/NR dapat dilihat pada Gambar 4 dan Gambar 5.

Vulkanisat mulai mengalami perubahan atau reaksi ditunjukkan oleh penyimpangan terhadap garis horizontal. Pertama kali terjadi penurunan berat pada suhu $180-200^{\circ} \mathrm{C}$, karena adanya bahanbahan yang volatile seperti asam stearat dan air yang terlepas pada suhu sekitar $300^{\circ} \mathrm{C}$. Tahap berikutnya adalah carbon black sebagai bahan pengisi akan terdegradasi pada suhu $330^{\circ} \mathrm{C}$ dan terdegradasi sempurna pada suhu $450^{\circ} \mathrm{C}$. Tahap selanjutnya adalah degradasi dari polisoprena (NR) pada suhu $450-550^{\circ} \mathrm{C}$ (Nabil et al., 2014). Degradasi NR karena adanya oksida dan menipisnya ikatan silang sulfida. Gambar 4 menunjukkan semakin tinggi jumlah NR, persentase penurunan berat karena suhu semakin tinggi. Hasil uji TGA menunjukkan bahwa vulkanisat EPDM/NR mulai terdekomposisi pada suhu $250^{\circ} \mathrm{C}$. Pada kondisi pemanasan dinamis dekomposisi berlangsung pada suhu $230^{\circ} \mathrm{C}$ sampai $550^{\circ} \mathrm{C}$. Reaksi dekomposisi sempurna pada rentang suhu $520^{\circ} \mathrm{C}-800^{\circ} \mathrm{C}$ dengan $95 \%$ bahan terdekomposisi untuk vulkanisat

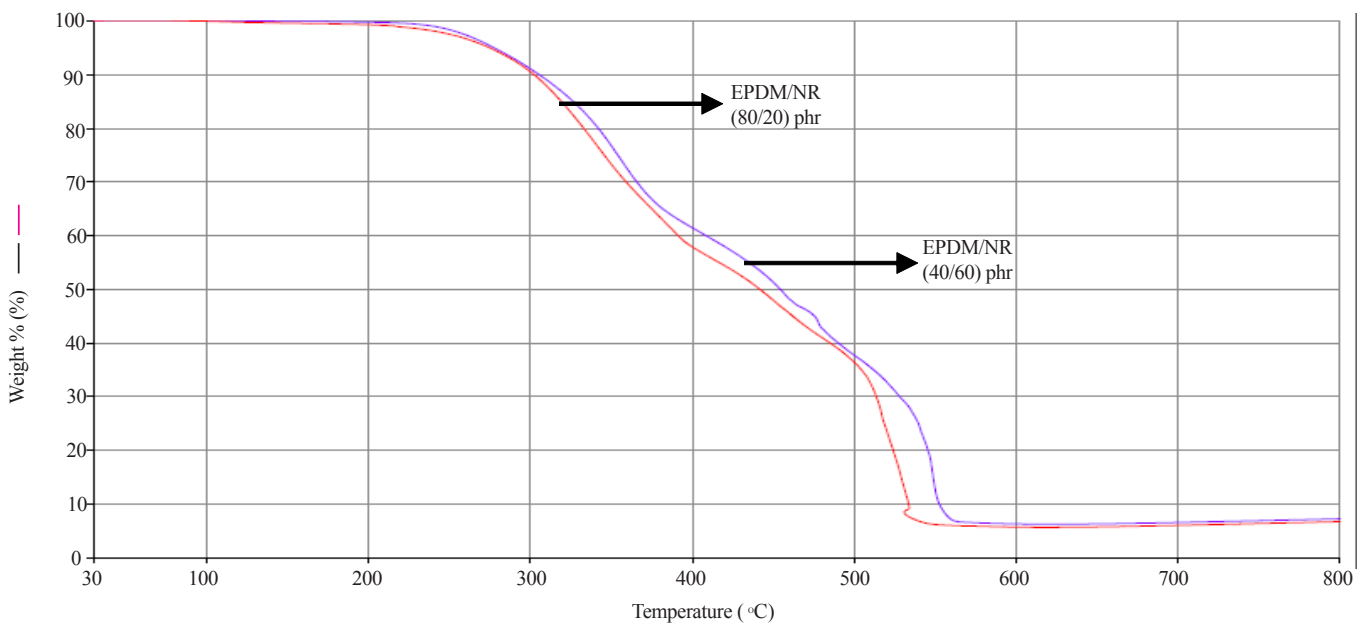

Gambar 4. TGA vulkanisat EPDM/NR.

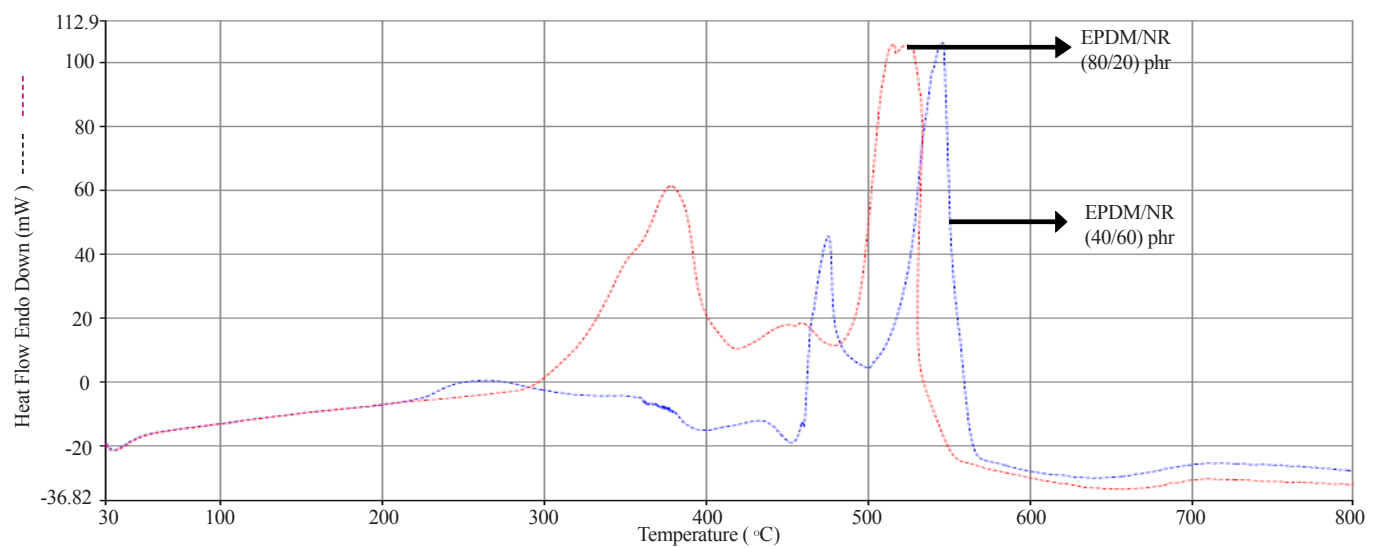

Gambar 5. DTA vulkanisat EPDM/NR. 
EPDM/NR (80/20) phr sedangkan untuk EPDM/ NR $(40 / 60)$ phr pada suhu $550^{\circ} \mathrm{C}-800^{\circ} \mathrm{C}$.

DTA digunakan untuk pengukuran karakteristik termal. Sampel yang digunakan seberat 12,795 mg dengan laju $5^{\circ} \mathrm{C} /$ menit. Perubahan termogram DTA disebabkan oleh perubahan panas reaksi yang tidak hanya dipengaruhi oleh perubahan masa vulkanisat tetapi juga oleh terjadinya proses reaksi perubahan struktur dan perubahan fase vulkanisat. Dari termogram DTA diperoleh perubahan kurva yang menunjukkan adanya perubahan massa panas reaksi. Hasil uji DTA (Gambar 5) menunjukkan terjadi reaksi eksotermis (pengeluaran panas). Puncak dekomposisi vulkanisat terjadi pada suhu $520^{\circ} \mathrm{C}$, untuk vulkanisat karet EPDM/NR $(80 / 20)$ phr dan suhu $550^{\circ} \mathrm{C}$ untuk vulkanisat EPDM/NR (60/40) phr.

\section{Swelling vulkanisat EPDM/NR}

Swelling pada vulkanisat karet merupakan proses difusi. Sejumlah solvent akan terdifusi ke pori-pori karet sampai mencapai kesetimbangan (Indrajati et al., 2012). Derajat swelling dinyatakan dalam jumlah cairan (liquid) yang diserap oleh polimer (Abu-Abdeen \& Elamer, 2010). Bahan baku karet alam (SIR 20 maupun EPDM) keduanya larut dalam n-heksana. Proses vulkanisasi dapat mengakibatkan campuran matang dan swelling menjadi berkurang, hal ini menunjukkan terjadinya ikatan kimia dan interfacial adhesion yang cukup baik.

Kepadatan ikatan silang campuran EPDM/ NR ditentukan oleh keseimbangan swelling. Rasio swelling ditentukan langsung dari derajat keterikatan silang, dimana apabila nilai rasio kecil maka derajat keterikatan silang besar. Rasio swelling adalah jumlah solvent uptake per berat karet (Ahmed et al., 2012). Besarnya swelling tergantung derajat crosslink dan intefacial adhesion. Gambar 6 menunjukkan bahwa semakin besar ka-

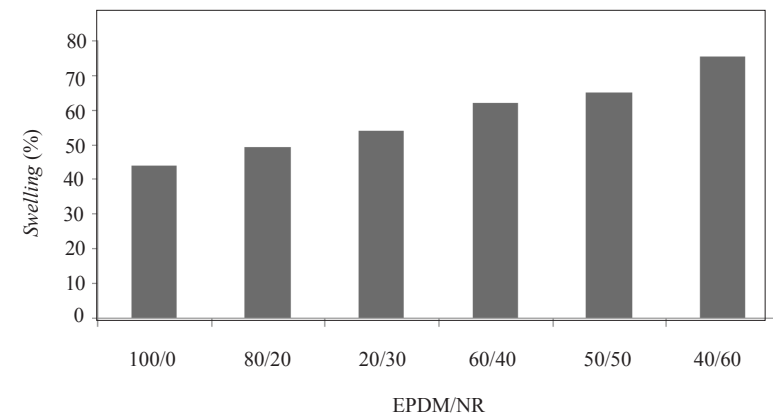

Gambar 6. Swelling EPDM/NR. dar karet alam derajat swelling semakin besar. Kepadatan ikatan silang merupakan rantai jaringan elastis aktif per satuan volume. Bila ditinjau dari penggunaan bahan karet, maka makin besar kadar EPDM nilai sweling kecil, hal ini terjadi karena EPDM merupakan material yang mempunyai ketahanan n-heksana yang baik. Adapun rentang nilai swelling vulkanisat karet EPDM/NR adalah 49, $10 \%-75,46 \%$.

\section{KESIMPULAN}

Pencampuran EPDM/NR dengan berbagai rasio menggunakan kompatibiliser maleat anhidrat berpengaruh terhadap sifat reologi, aging, termal, dan swelling campuran EPDM/NR. NR semakin besar mengakibatkan naiknya torsi maksimum dan waktu maksimun vulkanisasi. Penambahan EPDM memberikan sifat termal aging baik untuk seluruh rasio campuran EPDM/NR. Semakin tinggi jumlah EPDM dalam campuran EPDM/NR nilai swelling kecil. Sifat termal yang dilakukan dengan analisis TGA dan DTA menujukkan hasil bahwa kecepatan perubahan massa campuran EPDM/NR semakin tinggi dengan naiknya jumlah NR demikian pula terjadi pergeseran suhu dekomposisi dengan semakin tingginya jumlah NR.

\section{UCAPAN TERIMA KASIH}

Penulis mengucapkan terima kasih kepada Kepala Balai Besar Kulit, Karet dan Plastik yang sudah memberikan dana untuk dapat melakukan penelitian.

\section{DAFTAR PUSTAKA}

Abu-Abdeen, M., \& Elamer, I. (2010). Mechanical and swelling properties of thermoplastic elastomer blends. Materials \& Design, 31(2), 808-815.

Ahmed, K., Nizami, S., Raza, N., \& Mahmood, K. (2012). Mechanical, swelling, and thermal aging properties of marble sludge-natural rubber composites. International Journal of Industrial Chemistry, 3(1), 1-12, http://dx.doi.org/10.1186/2228-5547-3-21

Alipour, A., Naderi, G., Bakhshandeh, G. R., Vali, H., \& Shokoohi, S. (2011). Elastomer nanocomposites based on NR/EPDM/organoclay: Morphology and properties. International Polymer Processing, 26(1), 48-55, http://dx.doi.org/10.3139/217.2381

Arayapranee, W., \& Rempel, G. L. (2007). Effects of cashew nut shell liquid as a plasticizer on cure characteristics, processability, and mechanical properties of 50:50 NR/EPDM blends: A comparison with paraffin oil. Journal of Applied 
Polymer Science, 106(4), 2696-2702,

http://dx.doi.org/10.1002/app.25936

Arayapranee, W., \& Rempel, G. L. (2008). A comparative study of the cure characteristics, processability, mechanical properties, ageing, and morphology of rice husk ash, silica and carbon black filled $75: 25$ NR/EPDM blends. Journal of Applied Polymer Science, 109(2), 932-941, http://dx.doi.org/10.1002/app.28111

Arayapranee, W., \& Rempel, G. L. (2013). Effects of polarity on the filler-rubber interaction and properties of silica filled grafted natural rubber composites. Journal of Polymers, 2013, 1-9, http://dx.doi.org/10.1155/2013/279529

Botros, S. H., Moustafa, A. F., \& Essa, M. M. (2009). Properties and morphologies of elastomer blends modified with EPDM- g -poly[2-dimethylamino ethylmethacrylate]. Journal of Applied Polymer Science, 114(4), 2547-2554, http://dx.doi.org/10.1002/app.30820

Indrajati, I. N., Dewi, I. R., \& Irwanto, D. (2012). Pengaruh variasi rasio $\mathrm{HAF} / \mathrm{SRF}$ terhadap sifat vulkanisat NBR. Majalah Kulit, Karet, dan Plastik, 28(2), 59-68, http://dx.doi.org/10.20543/mkkp.v28i2.106

Indrajati, I. N., \& Sholeh, M. (2014). Pengaruh rasio MBTS/ZDEC pada campuran karet alam dan etilen propilen diena yang dibuat dengan teknik kontrol migrasi curatives. Majalah Kulit, Karet, dan Plastik, 30(1), 43-52, http://dx.doi.org/10.20543/mkkp.v30i1.124

Lewis, C., Bunyung, S., \& Kiatkamjornwong, S. (2003). Rheological properties and compatibility of NR/EPDM and NR/brominated EPDM blends. Journal of Applied Polymer Science, 89(3), 837847, http://dx.doi.org/10.1002/app.12329

Motaung, T. E., Luyt, A. S., \& Thomas, S. (2011). Morphology and properties of NR/EPDM rubber blends filled with small amounts of titania nanoparticles. Polymer Composites, 32(8), 12891296 , http://dx.doi.org/10.1002/pc. 21150

Nabil, H., Ismail, H., \& Azura, A. R. (2013a). Compounding, mechanical and morphological properties of carbon-black-filled natural rubber/ recycled ethylene-propylene-diene-monomer (NR/R-EPDM) blends. Polymer Testing, 32(2), 385-393, http://dx.doi.org/10.1016/j. polymertesting.2012.11.003
Nabil, H., Ismail, H., \& Azura, A. R. (2013b). Effects of virgin Ethylene-Propylene-Diene-Monomer and its preheating time on the properties of natural rubber/recycled Ethylene-Propylene-DieneMonomer blends. Materials \& Design, 50, 27-37, http://dx.doi.org/10.1016/j.matdes.2013.02.086

Nabil, H., Ismail, H., \& Azura, A. R. (2014). Thermal stability and aging characteristics of (natural rubber)/(wasteethylene-propylene-dienemonomer terpolymer) blends. Journal of Vinyl and Additive Technology, 20(2), 99-107, http://dx.doi.org/10.1002/vnl.21334

Patcharaphun, S., Chookaew, W., \& Tungkeunkunt, T. (2011). Influence of thermal and oil aging on weldline strength of NR / EPDM and NR / NBR blends. Kasetsart Journal - Natural Science, 45, 909-916.

Razak, J. A., Ahmad, S. H., Ratnam, C. T., Mahamood, M. A., Yaakub, J., \& Mohamad, N. (2014). NR/ EPDM elastomeric rubber blend miscibility evaluation by two-level fractional factorial design of experiment. In THE 2014 UKM FST Postgraduate Colloquium: Proceedings of the Universiti Kebangsaan Malaysia, Faculty of Science and Technology 2014 Postgraduate Colloquium, 1614(82-89), http://dx.doi.org/10.1063/1.4895176

Sahakaro, K., Pongpaiboon, C., \& Nakason, C. (2009). Improved mechanical properties of NR/EPDM blends by controlling the migration of curative and filler via reactive processing technique. Journal of Applied Polymer Science, 111(4), 2035-2043, http://dx.doi.org/10.1002/app.29193

Sirqueira, A. S., \& Soares, B. G. (2007a). Compatibilization of natural rubber/EPDM blends by anhydride- and mercapto-functionalized copolymers. Journal of Macromolecular Science, Part B: Physics 46(4), 639-650, http://dx.doi.org/10.1080/00222340701386569

Sirqueira, A. S., \& Soares, B. G. (2007b). The Effect of functionalized ethylene propylene diene rubber (EPDM) on the kinetics of sulfur vulcanization of normal rubber/EPDM blends. Macromolecular Materials and Engineering, 292(1), 62-69, http://dx.doi.org/10.1002/mame.200600332 
